\title{
Die Kerkbode en die viering van Geloftedag, 1910-2010
}

\author{
Froneman, JD \\ Noordwes-Universiteit, Potchefstroomkampus \\ Jd.Froneman@nwu.ac.za
}

\begin{abstract}
The Kerkbode and the commemoration of the Day of the Covenant, 1910-2010

The commemoration of the former Day of the Covenant was crucial in the development of Afrikaner nationalism and the apartheid ideology, providing theological grounding for twentieth century Afrikaner political philosophy. This article examines how the Kerkbode, official organ of the Dutch Reformed Church in South Africa, supported the dominant view of the commemoration, i.e. that God gave a military victory to the Voortrekkers over the Zulu's, confirming the right of the Voortrekkers (and their descendants) to their own state. From 1910-1990 the editors of the Kerkbode generally supported the fundamentals of the myth (with a single exception in 1920). As the apartheid era came to a close, the Kerkbode started to question these principles, until all references to the Day of the Covenant (since 1996, the Day of Reconciliation) were dropped, only to reappear again. Using the multi-step flow theory one can argue that the Kerkbode helped perpetuate the conventional understanding of the Day of the Covenant, as it may well have influenced the eventual demise of the widespread commemoration of the day.
\end{abstract}

\section{Keywords}

Day of the Covenant, Apartheid, Kerkbode, Media effects, Dutch Reformed Church

\section{Inleiding}

Die Kerkbode ${ }^{1}$ het as amptelike blad van die Nederduitse Gereformeerde Kerk waarskynlik 'n belangrike funksie gehad in die vestiging en

1 Die blad se naam is deur die jare aangepas van De Kerkbode tot Die Kerkbode en die huidige Kerkbode. Die bronverwysings en enige direkte aanhalings reflekteer hierdie 
instandhouding van Geloftedagfeeste (of dan Dingaansdagfeeste, soos dit vroeër genoem is). Hierdie gedenkdag was van 1910 (met Uniewording) tot 1993 (pas voor die aanbreek van 'n nuwe staatkundige bestel) 'n amptelike vakansiedag en is wyd in Afrikanernasionalistiese kringe - en daarom ook in kerklike konteks - gevier. Sedert 1994 word 16 Desember Versoeningsdag genoem.

Die veranderende rol wat die Kerkbode as agendasteller en meningsvormer deur die jare gespeel het in die legitimering en instandhouding van Geloftedag onder Afrikaners, word hier ondersoek aan die hand van die dekking wat Geloftedag oor 'n tydperk van 'n honderd jaar in die blad geniet het.

Die belang daarvan is dat Geloftedag 'n sentrale plek in die volksgodsdiens van die Afrikaner ingeneem het en regstreeks in verband gebring sou kon word met die Afrikaner se strewe om as geroepe volk (indien dan nie uitverkore volk) 'n staanplek, liefs afsonderlik, te kan inneem. Kortom, Geloftedag en die apartheidsideologie was/is deel van dieselfde paradigma. Groter begrip van Geloftedag as deel van die Afrikanernasionalistiese diskoers kan lei tot beter begrip van hoe die apartheidsideologie in die 20e eeu beslag gekry het. Daarom is dit ook nodig om te let op die media (veral kerklike media) se hantering van die tema, iets wat nog nie elders in enige detail gedoen is nie.

Die hoofvraag wat gevolglik hier aan die orde gestel word, is hoe die Kerkbode as amptelike blad van die NG Kerk lidmate se denke en praktyke rakende Geloftedag help vorm het. Pas ná die empiriese gedeelte waar artikels oor Geloftedag aangehaal word, word enkele vrae gestel en aan die hand van teoretiese perspektiewe beantwoord.

Die tema kan uiteraard uit verskillende perspektiewe benader word, maar die bedoeling is hier om enkele mediateoretiese perspektiewe binne 'n mediahistoriese konteks aan te bied wat naas teologiese en ander perspektiewe lig kan werp op hierdie aspek van die apartheidteologie en gepaardgaande nasionalistiese ideologie. 
Twee teoretiese uitgangspunte word gebruik: ten eerste aanvaar ek dat die media 'n agendastellingsfunksie het wat mede-bepaal waaroor gebruikers dink, praat en doen. Agendastelling (dus die agenda wat 'n blad aan die orde stel) word deur die proses van raming verder gevoer en bepaal hoe inligting en menings aan lesers deurgegee word. Dit speel weer 'n rol in die konstruksie van betekenis. Ten tweede word die multistapvloeimodel betrek omdat dit help verklaar waarom 'n blad 'n invloed op mense kan hê wat dit dalk nie eens gelees het nie (De Beer \& Botha 2008:238-240; Fourie 2007:238, 239, 242-246; DeFleur \& Dennis 1991:560-565; Steinberg 2007:266-268). Laasgenoemde is belangrik omdat dit die belang (al dan nie) van die Kerkbode se dekking van Geloftedag uitlig.

Die empiriese ondersoek behels 'n kwalitatiewe inhoudsanalise van die Kerkbode se dekking van Geloftedag in die tydperk 1910-2010 (dus 101 jaar), in die besonder die redaksionele kommentaar en ander tersaaklike artikels.

\section{Geloftedag}

Die viering van Geloftedag het sy ontstaan gehad by die gelofte wat 'n groep Voortrekkers in 1838, pas voor die Slag van Bloedrivier, onder leiding van Sarel Cilliers afgelê het (Visagie 2012:142,143). Hoewel die presiese bewoording van die oorspronklike gelofte onbekend is, het dit min of meer gelui dat sou God aan hulle (die Voortrekkers) die oorwinning oor die Zoeloe-magte van Dingaan gee, die dag jaarliks as 'n dankdag herdenk sal word (vgl Die Kerkbode, 16 Desember 1970; Strydom, 1952:94).

Geloftedag (of dan vroeër Dingaansdag) is met wisselende gereeldheid en ook op heel diverse wyses van 1838 tot 1909 gevier (Bailey 2002:111-114). Dit het in 1864 'n kerklike vakansiedag in Natal geword, die volgende jaar'n amptelike vakansiedag in die Zuid-Afrikaanse Republiek en so ook in 1894 in die Vrystaatse Republiek. In die Kaapprovinsie is die dag hier en daar gevier, maar dit het eers sedert 1911 'n landswye fees (onder Afrikaners) geword (Bailey 2002:114; Visagie 2002:96,97).

Volgens Van der Merwe (2012) is die herdenking van die Gelofte en die oorwinning by Bloedrivier "deur politieke, godsdienstige en gemeenskapsleiers gebruik om aan Afrikaners hulle konteks te verduidelik. Hierdeur is die vuur van Afrikaner-nasionalisme aangeblaas". 
In 1938 het die gelofte 'n sentrale plek by die Voortrekkereeufees gekry, wat sy hoogtepunt op 16 Desember in Pretoria bereik het (vgl Giliomee 2003:432,433) en ook met die inwyding van die Voortrekkermonument in 1949 (Visagie 2002:97).

Teen 1952 word in die driehonderdjarige feesboek van die Nederduitse Gereformeerde Kerk soos volg oor die gelofte geskryf: "Die Gelofte is inderdaad 'n teken van die ware godsvrug van die Voortrekkers, 'n voorbeeld van hul kinderlike vertroue in Sy almag. [Die slag] was 'n stryd van die apostels van die Lig teen die kinders van die Duisternis" (Strydom 1952:93). Dié interpretasie was een van vele. Hoe die Kerkbode en sy medewerkers dit gesien het, word weldra beskryf.

Intussen is die dag formeel tot Geloftedag geproklameer en het Sondagswetgewing vir die dag gegeld. Visagie (2002:97) merk op:

Dit is begryplik dat 16 Desember nie vir die onderskeie kultuurgroepe in Suid-Afrika dieselfde betekenis het nie. Die vertolking van Geloftedag as 'n oorwinning van wit oor swart het die groot meerderheid persone van kleur asook 'n groeiende aantal blankes vervreem ...

Visagie is dalk reg dat Geloftedag eens so beskou is, maar daar is min twyfel dat Afrikaners hulle later in die twintigste eeu al minder aan die dag gebonde gevoel het. Hierdie proses, wat met die opkoms van "sekulêre religieë" en 'n "plaaslike industriële kapitalisme" gepaard gegaan het, het reeds in die 1960's sy merk begin laat (De Klerk 1976:300-303; De Klerk 1979:16,17). Met die ou Afrikanerdoelwit van 'n republiek in 1961 bereik en politieke mag stewig in die hande van die Nasionale Party, het die ou middelpuntvlietende kragte afgeneem en in die 1970's het Afrikanernasionalisme reeds beduidend begin verbrokkel (vgl Grobler 2007:215; Scholtz 2011).

'n Betekenisvolle politieke breuk vind eers in 1982 in Afrikanergeledere plaas en skaar behoudende Afrikaners hulle nou in groot getalle by die Konserwatiewe Party van dr Andries Treurnicht, oudredakteur van die Kerkbode (Giliomee 2003:606-609).

Die ANC se politieke en militêre weerstand teen apartheid dra in die 1980's en 1990's toenemend by tot nuwe denke oor sake soos Geloftedag in 'n 
multikulturele en multigodsdienstige omgewing - alles faktore wat die weg gebaan het vir die omskepping in 1994 van Geloftedag in Versoeningsdag (vgl Visagie 2002:97).

Grobler (2007:215) voer aan:

Een van die mees verdoemende aanduidings van die afname in Afrikanernasionalisme is die gebrek aan belangstelling wat die nuwe geslag Afrikaners in tradisionele volksfeeste toon ... Saamtrekke op Geloftedag ... word deur net 'n minimale persentasie van die Afrikanerbevolking ondersteun.

Hierdie waarneming word ook deur Van der Merwe (2011) se navorsing ondersteun. In sommige Afrikanergeledere word die dag egter steeds as Geloftedag gevier. Verskeie webwerwe handel nog oor die dag en berigte in Afrikaanse dagblaaie gee steeds aandag daaraan, maar nie sonder briewe en artikels nie wat die viering daarvan afwys of bloot krities daarteenoor staan. So skryf die historikus en politieke kommentator, Leopold Scholtz (2011), in Beeld:

Baie groepe - lande, volke, politieke partye of wat ook al - wat deur 'n taai stryd moes gaan om hulle doel te bereik, het die behoefte aan 'n heldhaftige geskiedenis wat opnuut gekonstrueer word. Die Afrikaners het dit met hulle geskiedenis van die 19de eeu tot die Rebellie van 1914 gedoen. In die proses het hulle wat die sosioloog, T Dunbar Moodie, genoem het 'n "civil religion" geskep - 'n heilige geskiedenis wat nie bevraagteken mog word nie.

Scholtz voer verder aan dat die historikus prof Floors van Jaarsveld juis in die 1970's geteer en geveer is omdat hy die "mite oor Geloftedag aan die kaak gestel het".

Ondanks hierdie en ander polemiese geskrifte in resente tye, het die belang van Geloftedag (en die gepaard gaande teologie wat daaromheen ontwikkel is) in die breër diskoers vervaag. Geloftedag kom nie prominent in Giliomee (2004) se omvangryke Die Afrikaners of Giliomee en Mbenga (2007) se Nuwe geskiedenis van Suid-Afrika voor nie. In die meer onlangse Geskiedenis van Suid-Afrika, onder redaksie van Fransjohan Pretorius, skryf Giliomee (2012:223) wel as volg daaroor: 
Die idee van 'n uitverkore volk - wat gevoed is deur die oorwinning by Bloedrivier - is een van die sterkste mites van 'n nasionalisme ... Sulke volksmites kan eers wyd versprei word wanneer mense boeke en koerante begin lees en politieke en kulturele organisasies stig (kyk ook Visagie 2012:142,143).

In die tyd ná 1910 het hierdie ontwikkelings inderdaad plaasgevind en toenemend 'n rol in die Afrikaner se denke en optrede gespeel (vgl Giliomee 2004:352,353; Diederichs \& De Beer 1998:95-97; Froneman 1995:67-70; $135-140 ; 215-218)$ en bevestig die nodigheid om erkenning te gee aan media ánders as die Kerkbode en hulle rol om Geloftedag as belangrike, selfs sentrale, volksfees te vestig. Media wat genoem moet word, maar wat nie in hierdie artikel verdere aandag geniet nie, is die Afrikaanse koerante en tydskrifte met sterk Afrikanernasionalistiese inslag (soos Die Burger, Volksblad, Transvaler en Huisgenoot) (vgl Muller 1990:754-760; Steyn 1992:161-181; Oosthuysen \& Scholtz 1992:210-219; Froneman 2004) en die Afrikaanse radiodiens van die SAUK (Froneman 2012). Hulle het sonder twyfel 'n beduidende rol gespeel deur publisiteit aan Geloftedagvierings te gee, asook uitsendings wat inhoud aan die karakter van die dag help gee het.

Die verband tussen die gelofte (en die gebeure by Bloedrivier in 1838) en 'n beleid wat voortbestaan moes verseker, is klaarblyklik: indien God 'n volk (of dan 'n deel van hierdie volk-in-wording) op wonderbaarlike wyse red (soos 'n Israel van ouds), dan het hierdie volk duidelik 'n Godgegewe reg op voortbestaan. Hierdie siening (of verduideliking) sou as 'n mite beskryf kon word, wat geen uitspraak oor die waarheid daarvan (al dan nie) inhou nie.

Die fase van 1910 tot rondom 1994, wat in die teken van die NG Kerk se ondersteuning van apartheid (of dan'n beleid van afsonderlike ontwikkeling of aparte vryhede) staan, was gegrond op die standpunt dat die Afrikaner 'n reg gehad het om as aparte volk voort te bestaan. Die NG Kerk het 'n Bybelse grondslag aan die beleid van apartheid verskaf en die belangrikste dag op die kalender van hierdie burgerlike godsdiens was noodwendig Geloftedag, 16 Desember. Dat die Kerkbode, as amptelike blad van die NG Kerk, dit lank aktief sou ondersteun, was voor die hand liggend. 
Dit laat twee belangrike vrae ontstaan:

Wat het die Kerkbode van die gelofte gemaak en watter rol het die blad moontlik gespeel in die viering van die dag in die twintigste eeu - eers as Dingaansdag en later as Geloftedag?

Antwoorde hierop kan groter begrip gee, nie net van die invloed van 'n bepaalde blad nie, maar ook die dinamiek van 'n ontvouende ideologie help verduidelik.

\section{Amptelike blad van die NG Kerk}

Die Kerkbode het in 1849 as De Gereformeerde Kerkbode in Zuid-Afrika (Olivier 1998:7) ontstaan. Eers in 1884 word dit die amptelike blad van die Nederduitse Gereformeerde Kerk van Suid-Afrika (Olivier 1998:33-35), dus die "Kaapse Kerk". Na die gebeure in 1862 (toe die band tussen die provinsiale sinodes verbreek is), is die NG Kerk eers in 1962 weer in 'n algemene sinodale verband saamgesnoer (Hofmeyr 2002a:198,199).

Reeds in 1910 verenig twee noordelike kerkblaaie met De Kerkbode onder die redakteurskap van ds Johannes du Plessis en behou dié blad sy posisie as amptelike blad van die NG Kerk deur die hele twintigste eeu, hoewel die gesag van die blad steeds verskillend geïnterpreteer is.

Van 1910 tot op hede het die blad 'n hele aantal redakteurs gehad. Dit kon 'n invloed op die spesifieke hantering van Geloftedag deur die Kerkbode gehad het, soos later beredeneer sal word.

Die tydperk wat hier ondersoek word, is 1910 tot 2010, dus van die stigting van die Unie van Suid-Afrika (die jaar waarin Dingaansdag vir die eerste keer 'n landswye openbare vakansiedag geword het), tot 'n eeu later (toe die land in 'n heel nuwe bedeling ingebed was). Die staatkundige veranderings van 1994 asook ander verskuiwings in denke, maak dit noodsaaklik om die studie effe verder as 1994 te trek. Die verskuiwing in denke oor Geloftedag in die postapartheidsera sal weldra duidelik word.

\section{Moontlike invloede}

Die vraag na watter invloed die Kerkbode op die viering van Geloftedag kon uitgeoefen het, vra na die invloed van die NG Kerk in die algemeen en dié van die media in die besonder op mediagebruikers. 
Die invloed en rol van die NG Kerk (tot 1994) is meermale krities en aanprysend beskryf en beredeneer (vgl De Gruchy 1986:69-85; Froneman 2000; Hofmeyr 2002b; Giliomee \& Mbenga 2007). Hieroor sal menings noodwendig verskil. Die aanname word hier ondersteun dat die NG Kerk in die twintigste eeu verreweg die dominante kerk onder Afrikaners was. Maar hier gaan dit veral oor die Kerkbode.

In sy Bode op die spoor van die Woord, gee Olivier (1998) 'n samevatting van die blad se geskiedenis en rol, wat saam met verskeie herdenkingsbylae (Die Kerkbode 140, 1989; Die Kerkbode, Feesuitgawe 150 jaar, 1999; Kerkbode 155 jaar, 2004) insig bied in 'n soms komplekse sameloop van omstandighede en sienings.

Hoewel bogenoemde belangrik is in die (kontekstuele) verstaan van die Kerkbode, is dit noodsaaklik om ook mediakundige perspektief te soek ten einde begrip te verkry van die moontlike invloed wat die blad in die algemeen - en wat hierdie artikel betref, sy rol in die vorming van gedagtes oor Geloftedag - gehad het.

Die invloed van die media staan in die sentrum van medianavorsing wat al vir meer as 80 jaar gedoen word. Die uitgangspunt van hierdie studie, soos trouens alle mediastudies, is daarom dat die media wél 'n invloed kan hê (vgl McQuail 1987:251). Hierop word later uitgebrei.

Hierdie artikel probeer egter primêr vasstel hoe Geloftedag in die blad gefigureer het. Uitgawes uit elke dekade is eers nagegaan, naamlik dié van 1910, 1911, 1914, 1920, 1930, 1938, 1940, 1949, 1951, 1961, 1966, 1970, 1971, 1982 (toe die Kerkbode 'n koerantformaat gekry het), 1983, 1991, 1996, 2001, 2007, 2009 en 2010. Die navorsing sluit ook uitgawes in wat in histories belangrike jare verskyn het, asook uitgawes van 1969 en 2007 sodat uitgawes ondersoek is wat onder alle redakteurs van 1910 tot 2010 gepubliseer is. (Ds Anton Pienaar het einde 2010 uitgetree en 'n logiese afsnypunt gegee.) Daarmee word die potensieel belangrike rol van 'n redakteur as agendasteller en ramer van 'n bepaalde boodskap beklemtoon (vgl Vosloo, 1982:12-24; Steyn 2002:76-96; Van Deventer 1998).

'n Ander vraag wat opduik en wat kortliks beredeneer sal word, is of die kern van die Kerkbode se moontlike rol rakende Geloftedag nie veral gelê het in die feit dat predikante (vermoedelik) getroue lesers van die blad was 
nie, en dat hulle prediking daardeur beïnvloed sou gewees het. So het die Kerkbode se invloed potensieel wyer gestrek.

\section{Kerkbode en Geloftedag (1910-2010)}

Hoewel redakteurs van die Kerkbode nooit vrye teuels gehad het nie - geen redakteurs het dit ooit nie (vgl Froneman 2013; Gaum 2004:76-78) - het hulle elk 'n bepaalde stempel op die blad en sy dekking van Geloftedag afgedruk. Daarom word die blad se dekking direk gekoppel aan die opeenvolgende redakteurskappe.

\section{Ds J du Plessis (1910-12)}

Du Plessis was twee keer redakteur van die blad, eers van 1905-06 en toe weer vir 'n kort periode van 1910-12 voordat hy skielik bedank en vertrek het om hom te gaan voorberei vir werk op die sendingterrein (Gaum 2010). Hy was in allerlei polemieke betrokke en geen naprater van enige kerklike establishment nie (kyk Olivier 1998:60-70).

Die eerste viering van Geloftedag as landswye, amptelike vakansiedag het die Kerkbode ongesiens verbygegaan. Maar in 1911 verskyn 'n oordenking deur eerw GJ Willemse waarin 'n direkte parallel tussen die geskiedenis van Israel en die Voortrekkers getrek word (Willemse 1911). Die skrywer voeg in die gees van die tyd by: "Laat de Unie, waarin we ons thans beroemen, ook een Unie vereenig met God Zijn; en de God onzer vaderen zal ook met ons zijn tot in lengte van dagen."

Hoewel Du Plessis oor allerlei ander teologiese sake eiesoortige standpunte ingeneem het wat hom in botsing met sommige lidmate gebring het, het hy klaarblyklik nie oor Dingaansdag 'n andersoortige stem laat hoor nie.

\section{Ds GS Malan (1913-1918)}

Met die vertrek van ds Johannes du Plessis, sukkel die betrokke kommissie om 'n geskikte persoon vir die pos te vind (Olivier 1998:71). Ds Geo S Malan aanvaar wel met verloop van tyd die beroep en neem hom voor om 'n blad vir "gewone lesers" uit te bring.

In 1914 breek die Eerste Wêreldoorlog uit en vind die Rebellie in reaksie op die regering se optrede teen Duitsland plaas (Grobler 2007:142-145). 
Groot verdeeldheid heers onder lidmate van die kerk en Malan se versigtige benadering is te verstane. Trouens, hyself beskryf by sy uittrede in 1918 sy styl as een wat nie die algemene mening van die kerk vooruit geloop het nie, maar veeleer wou volg (Olivier 1998:75). Hierdie benadering het dalk bygedra tot die styging in intekenare tot 8500 , maar daar mag ander faktore gewees het.

Die dekking van Dingaansdag (soos dit toe nog bekend was) was in Malan se tyd onopvallend. 'n Artikel waarin ds GBA Gerdener vir Piet Retief eer, is al verwysing in 1914 daarna (Gerdener 1914). Hier kon die politieke woelinge van die jaar 'n soberende rol gespeel het.

In 1918 neem Malan afskeid van die blad en staan ds Piet Meiring vir 'n tydjie in as redakteur, alvorens ds JD Kestell beroep is.

\section{Ds JD Kestell (1919-20)}

Ds Kestell was bekend as volksman en veldprediker tydens die AngloBoere-oorlog. Hy was net van Februarie 1919 tot einde 1920 redakteur en kon dus geen groot invloed uitoefen nie. Hy verwys self na die blad as "'n kleine tydschriffie wat eenmaal per maand uitkom" (Olivier 1998:778).

Tog vra De Kerkbode van 16.12.1920 - pas voor Kestell sy emeritaat aanvaar het en die blad verlaat het - belangrike vrae in 'n hoofartikel oor die viering van Geloftedag: Is dit nie 'n verheerliking van imperialisme nie? Prikkel dit nie swart mense "tot onluste en weerstand" nie?

Die artikel sê voorts: "Daar is geen sprake in ons Dingaansdagvieringe van 'n gejuig oor die verslane inboorling nie - of van 'n gekraai oor die ondergang van swak en weerlose stamme." Wel is dit 'n "nasionale fees" en sou die Boererepublieke waarskynlik nie gestig gewees het, was dit nie vir die oorwinning nie, maar (dit is) "bowenal 'n godsdienstige fees".

Of ds Kestell self hierdie artikel geskryf het, is onbekend.

\section{Ds PGJ Meiring (1921-38)}

$\mathrm{Na}$ ds Kestell se uittrede, sukkel die Kerkbode weer om 'n redakteur te kry. Na drie onsuksesvolle pogings, word nogmaals op ds Meiring teruggeval. Uiteindelik stem hy in om redakteur te word, wat hy saam met 'n gemeentepos beklee (Olivier 1998:80,81). 
Dit blyk asof die blad onder Meiring se joernalistieke vaardighede nou 'n bloeityd ingaan. Die Kerkbode word "een van die mees gelese blaaie in SuidAfrika" (Dreyer, aangehaal deur Olivier, 1998:81). Van 'n blad wat gesukkel het om 'n redakteur te kry, het die blad nou trefkrag gekry "waarmee rekening gehou moes word".

Wel probeer die redakteur die blad grootliks buite die heftige stryd hou wat in hierdie jare tussen prof Johannes du Plessis (en sy blad, Het Zoeklicht) en prof EE van Rooyen (en dr DR Snyman se blad, Die Ou Paaie) se uiteenlopende denkrigtings geheers het (Olivier 1998:87,88). Sommige wou egter juis hê hy moes standpunt inneem en het hom kwalik geneem dat hy geweier het omdat hy die saak as sub judice beskou het (Olivier 1998:91-97; $108 ; 122 ;$ Meiring s.a.:105). In die lig daarvan is 'n afwyking van tradisionele standpunte jeens Dingaansdag ondenkbaar, soos uit die volgende blyk.

De Kerkbode van 17.12.1930 bevat 'n artikel onder die opskrif “"n Dingaansdagbelofte". Dit vertel van 'n belofte wat Boere-krygsgevangenes in Indië onder leiding van ds DJ Viljoen afgelê het en wat as volg gelui het:

Ons bely voor die Here dat ons nie Dingaansdag soos 'n Sabbatdag gevier het nie, soos deur ons vaders beloof, en doen nou plegtig die belofte aan Hom dat ons met sy hulp voortaan 16 Desember saam met ons huisgesinne as 'n Sabbat tot sy eer sal vier, en as hy ons sal spaar en aan ons en ons volk die verlossing gee, ons Hom sal dien so lank ons lewe (De Swardt 1930).

Elders in dieselfde uitgawe verskyn 'n gedig deur GJ Diamond wat die ingrype van God uitdruklik aanvaar en so verwoord:

'n Swarte drom van Soeloes kom

Woes uitgedos, soos duiwels los,

Reg op die laer, waar manne klaar,

Berus in krag van hoër Mag (Diamond 1930).

Meiring tree in 1931 op eie versoek vir 'n tyd uit sy pos "tot toestande weer normaal is" (Olivier 1998:108). Na sy terugkeer 'n paar maande later, het die druk op hom (weens die Du Plessis-saak) egter nie verminder nie.

In 1932 verwys die Kerkbode na Dingaansdag en "die vaderland en sy belange wat blydskap en dankbaarheid” bring (Olivier 1998:117), terwyl 
die blad ook na die kerk as volkskerk verwys. Al was sy simpatie by prof Du Plessis, was sy lojaliteit "altyd by sy kerk" (Olivier 1998:129). Meiring was wat hierdie saak betref in die hoofstroom. Trouens, oor rassesake in die algemeen en die verbintenis tussen volk en kerk het die blad in pas met sinodes geskryf (vgl Olivier 1998:118). Die verbondsvolk van die Bybel en die Afrikanervolk is sonder meer deur die Kerkbode met mekaar gelyk gestel (Olivier 1998:124).

In die loop van 1938, wat gekenmerk is deur die simboliese ossewatrek na Pretoria, is ds Meiring in die tuig oorlede.

\section{Dr MJ van der Westhuyzen (1938-59)}

Ds Meiring se opvolger, dr Michiel van der Westhuizen, was 'n "versigtige” redakteur wat in strydwekkende sake'n neutrale posisie probeer inneem het. Hy het die beleid van sy kerk gerespekteer en nie ander idees gepropageer nie. Die Kerkbode was deurentyd simpatiek teenoor die Afrikaner en sy strewes, ook in die moeilike jare van die Tweede Wêreldoorlog (Gaum 2010).

Met die viering van die Voortrekkereeufees in 1938 het die siening van die Afrikanervolk as volk met 'n Godgewilde plek in Suid-Afrika nuwe momentum gekry. Die uitgawe pas voor Geloftedag, dié van 14.12.1938, dra 'n tekening van die Voortrekkermonument op die voorblad asook 'n tweede artikel deur ds AP Smit oor die Trekkerleier, Sarel Cilliers (Smit 1938).

In die uitgawes oor Geloftedag van 1940 en 1951 is egter geen verwysing na die viering nie. Twee bykomende uitgawes is daarom ondersoek: dié van 1945 en 1948, wat onderskeidelik die jare is waarin die Tweede Wêreldoorlog beëindig is en waarin die Nasionale Party die regering oorgeneem het. Daarin word wel dekking aan die dag gegee.

In die uitgawe van 28 November 1945 verskyn 'n artikel (klaarblyklik ingestuur en dus nie uit die pen van die redakteur nie) waar lidmate opgeroep word om die fees te gedenk. "Op 16 Desember is daar fees tot eer van die Here. Op daardie feesdag mag nie 'n enkele lid van ons volk gemis word nie."

Die artikel vervolg: 
$\mathrm{O}$, soveel vrae is daar wat ons dwing tot ongeveinsde dankbaarheid dat ons 'n verloste volk, 'n blanke volk met 'n selfstandige volkslewe en die dankbare nageslag is van 'n stoere, beginselvaste, koersvaste en voorbeeldige voorgeslag (Anon. 1945).

In 'n daaropvolgende uitgawe versterk ds AM Meiring in 'n preek die gangbare volksnasionalistiese verstaan van Geloftedag deur die beskouing te ondersteun dat die Afrikaner 'n uitverkore volk is (Meiring 1945).

Steeds onder redakteurskap van dr Van der Westhuizen verskyn 'n redaksionele hoofartikel in 1955 waarin die redakteur wel as volg standpunt inneem: Die dag mag nooit gesien word "as 'n dag van oorwinning van die blankes oor die inboorlinge nie ..." God was nie by Bloedrivier aan blankes se kant nie. Daarom is enige "wraakgedagtes, selfverheffing en oorwinningsroes" nie van pas nie. Aan so'n fees kan die kerk nie deelneem nie (Die Kerkbode 14.12.55). Dit eggo die waarskuwing uit 1920.

Dit kan aanvaar word dat dr Van der Westhuizen, wat die langste van al die Kerkbode se redakteurs die pos beklee het (van 1938 tot 1959), nie wesenlik afgewyk het van die bestaande gangbare interpretasie van die gelofte nie selfs nie toe hy bogenoemde vermaning laat hoor het nie. Sy standpunt was immers dat die Kerkbode geen ander standpunt kon hê as dié van die kerk nie (Olivier 1998:132).

\section{Dr AP Treurnicht (1960-67)}

Met die aanstelling van dr Andries Treurnicht in 1960 verander die trant merkbaar. Dr Treurnicht was, aldus Gaum (2010) "kort voor lank middein die kerklik-politieke woelinge". So het hy die "toon aangegee vir 'n storm van kritiek" op die Cottesloe-beraad wat in Desember 1960 onder beskerming van die Wêreldraad van Kerke gehou is. Die Kerkbode het veral sterk standpunt ingeneem teen die slotverklaring van die beraad waarin "matige kritiek teen die apartheidsbeleid" uitgespreek is.

Dr Treurnicht het hom tydens sy sewe jaar lange redakteurskap laat ken as kampvegter vir die Afrikanersaak en voorstander van konsekwente afsonderlike ontwikkeling in kerk en staat. Sy standpunte het wye aanklank in kerklike geledere gevind, en hy is mettertyd verkies tot assessor van sowel die Kaapse as die Algemene Sinode (Gaum 2010; vgl ook Olivier 1998:150,151). 
Sy verkiesing tot hierdie posisies is 'n aanduiding dat hy die mening van die meerderheid leraars en senior ouderlinge vertolk het, indien dan nie dié van alle gewone lidmate nie. Tog het die Kerkbode onder sy leiding geen groot sirkulasie gehad nie. Trouens, die sirkulasie van net meer as 23000 tot net meer as 20000 gedaal (Olivier 1998:148).

In Die Kerkbode van 13.1.1961 skryf hy onder die opskrif “Glo in jou volk!" dat Geloftedag nie maar'n fees van die Christendom se oorwinning oor die heidendom is nie. Die artikel vervolg: “... in eerste instansie was hierdie militêre triomf die redding en handhawing van 'n volk of 'n deel van 'n volk wat in sy fisieke bestaan met uitroeiing bedreig is ..."

Die blad sê die Afrikaner ken geen voorkeurposisie aan homself toe nie; anders sou die kerstening van heidense volke nie so 'n prominente plek gekry het nie. Tog word die "bestaansmoontlikhede" van die Afrikaner beklemtoon en die artikel afgesluit met die woorde: "Ons glo in ons volk!", 'n gedagte wat vroeër deur dr DF Malan bekend gemaak is. Die hoofartikel is deur'n artikel (deur dr Marius J Swart) oor President MT Steyn aangevul. Volgens die skrywer het Steyn geglo dat die oorwinning by Bloedrivier die "Bantoe onder ons voogdyskap geplaas" het (Swart 1961).

In latere jare word artikels van hierdie aard voortgesit. Die uitgawe van 14.12.1966 dra 'n foto van die Voortrekkermonument op die voorblad en prikkels wat lui: “n Volk se Vryheid" en "Die gelofte". Die gedagte aan vryheid word as volg deur dr Treurnicht in 'n hoofartikel uitgespel: "Waar ons met Geloftedag 'n groot reddingsdaad van God aan ons volk herdenk, laat ons bedink dat 'n volk wat waarlik bevry is ... vrug dra van Sy Koninkryk."

Treurnicht het in 1967 die eerste redakteur van Hoofstad, 'n Pretoriase middagblad, geword en is daarna na die voltydse politiek.

\section{Dr WGJ Lubbe (1967-70)}

$\mathrm{Na}$ dr. Treurnicht se bedanking, is dr Willie Lubbe as redakteur van die Kerkbode aangestel. Dr Lubbe was moderator van die Natalse Sinode en in sy kerklik-politieke benadering selfs meer behoudend as dr Treurnicht, aldus Gaum (2010). Dr Lubbe was minder as twee jaar in die stoel alvorens hy redakteur van Die Afrikaner, mondstuk van die Herstigte Nasionale Party, geword het. 
Verrassend min verskyn uit sy pen oor Geloftedag. In Desember 1967 was die redakteurskap nog formeel vakant, maar 'n hoofartikel verskyn wel onder die opskrif "Geloftedag as geestelike uitdaging" (Die Kerkbode 13.12.67). Die outeur is onbekend, maar kon Lubbe gewees het.

Die volgende jaar verskyn 'n vertaalde weergawe van ds GBA Gerdener se gepubliseerde rede van 1912 (Gerdener 1968). Dié teologie uit 1912 was klaarblyklik vir dr Lubbe nog geldig. Hy gee ook in die daaropvolgende jaar heelwat ruimte aan die Geloftefees.

\section{Ds GSJ Möller (1970-86)}

Dr Lubbe se opvolger, ds Tappies Möller, was by uitstek 'n vredemaker wat besef het hy moes "dubbeld versigtig" wees oor wat en hoe hy skryf (Olivier 1998:166). Anders as sy twee voorgangers, het hy geen politieke ambisies gehad nie, maar sy hantering van Geloftedag was nie wesenlik anders as enige van sy voorgangers nie. Trouens, onder ds Möller se redakteurskap verskyn 'n groot aantal artikels oor Geloftedag in die styl van die voorafgaande dekades.

Die uitgawe van 16.12.1970 dra 'n foto van Sarel Cilliers op die voorblad en prikkels vir artikels wat binne verskyn. Die hoofartikel beklemtoon dat "ons kinders opgevoed moet word om Geloftedag in ere te hou". Die artikel wys egter daarop dat "weinig Afrikanerouers hulleself aan die betekenis en viering van Geloftedag steur". Die standpunt word ook in 'n lesersbrief ingeneem: "Op baie plekke is daar geen byeenkomste meer nie" (Rossouw 1970), terwyl nog 'n briefskrywer meen 'n "piekniekgees” heers by sommige Geloftedagvieringe (Arendt 1970).

Ds AP van der Colf se artikel in die uitgawe van 8.12 .1971 bevestig nogmaals die fundamentele uitgangspunte van die apartheidsteologie (Van der Colf 1971). Dit verskyn pas voor die inwyding van die "gerestoureerde" slagveld by Bloedrivier. "Hier het ons volk die herbevestiging deur God self van ons nasieskap ontvang - maar hier het gelowiges hulself ook verbind om opnuut God se volk te wees," skryf dr Van der Colf. In dieselfde trant meen ds HJC Snijders: "Die Suid-Afrikaanse volk is verskuldig om die gelofte na te kom ... Geen enkele Christen-Suid-Afrikaner kan aan hierdie verpligting ontkom nie" (Snijders 1971). Nou word alle Christene hierby betrek. 
In 1982 word Die Kerkbode 'n koerant met 'n sterker klem op nuus. Die blad staan steeds onder ds Möller se redakteurskap en hy skryf in die uitgawe van 8.12.1982 'n hoofartikel onder die opskrif "Vier jou feesdae, betaal jou geloftes". Hoewel die artikel die viering van Geloftedag sterk ondersteun, slaan ds Möller se persoonlikheid en die realiteit van die dag deur as hy skryf: "Aan diegene wat hulle nie deur die gelofte gebonde ag nie, vra ons ten minste begrip en eerbiediging van die sentiment van die Afrikaners wat hulle as nageslag van die Voortrekkers aan die gelofte gebonde ag."

Die koerantformaat van die Kerkbode het nie 'n einde aan meningsartikels oor Geloftedag gebring nie. In die uitgawe van 2.12.1983 verskyn, benewens 'n hoofartikel, 'n artikel waarin prof HB Thom se laaste Geloftedagrede vervat is (Thom 1983). Die artikel onder die opskrif "Uiteenlopende opvattings oor Geloftedag" (Van Vuuren 1983) asook een deur ds G Madder Steyn, waarin hy beweer dat Geloftedag "vir baie mense 'n verleentheid" geword het, dui op die groeiende ongemak met die tradisionele opvattings oor Geloftedag (Steyn 1983).

Dit blyk dus dat die gety gedraai het en dat Geloftedag nie meer so 'n sentrale plek by gewone lidmate van die NG Kerk ingeneem het nie. Hierteen probeer die Kerkbode nog vir oulaas walgooi.

\section{Dr FM Gaum (1989-2004)}

In 1986 neem dr Frits Gaum by ds. Möller oor as redakteur. Die gebruiklike hoofartikel verskyn steeds rondom Geloftedag, ook nadat die politiek in 1990 'n nuwe rigting ingeslaan het met die aankondiging deur pres FW de Klerk dat apartheid beëindig gaan word (Giliomee 2004:593-635).

Die Algemene Sinode van die NG Kerk bevestig nietemin in dieselfde jaar "dat Geloftedag gevier behoort te word" en lidmate is aangemoedig om hulle met die "historiese en godsdienstige betekenis van die dag te vereenselwig” (Van der Merwe 2012).

In die uitgawe van 13.12.1991 skryf die Kerkbode: "Geloftedag sê elke jaar weer vir elke gelowige Afrikaner: God het met dié volk waarvan jy deel is, 'n doel." Maar by implikasie sou God met elke volk'n doel kon hê.

Teen 1996 is Geloftedag formeel deur Versoeningsdag vervang. Die Kerkbode, wat nou aangevul is deur Algemene Kerkbode (wat in Afrikaanse 
dagblaaie verskyn het en ook onder Gaum se redakteurskap was) skryf nie self oor Geloftedag/Versoeningsdag nie, maar in die Algemene Kerkbode se uitgawe van 13/14 Desember verskyn wel'n hoofartikel daaroor. Die artikel stel die byna pynlike vraag: "Was alles op stuk van sake tog tevergeefs? ... En die uitredding van 1838 , was dit op stuk van sake maar 'n fratsvoorval?" Hiermee verwoord die redakteur waarskynlik die groeiende verskuiwing in denke oor Geloftedag.

Die blad pleit dat Versoeningsdag 'n dag van nadenke, verootmoediging en versoening moet wees. "Die Slag van Bloedrivier het in sy plan 'n plek gehad, soos ook die Algemene Verkiesing van 1948 en dié van 1994." Daarmee word die gebeure van Bloedrivier nou fundamenteel in 'n ander lig gestel as in die voorafgaande eeu.

Die Kerkbode self dra op 20.12.1996 'n voorbladhoofberig waarin die redakteur se Geloftedagboodskap in die Groote Kerk weergegee word. Die klem val egter op versoening (in aansluiting by die dag se nuwe naam) en nie meer op die tradisionele viering van Geloftedag nie.

Die jaar daarna skryf Gaum in 'n hoofartikel: "Nog selde het Afrikaners Geloftedag met soveel gemengde gevoelens belewe as vanjaar (Die Kerkbode 19.12.1997) - dit teen die agtergrond van 'n besef dat "die meeste van die NG Kerk se lidmate steeds uit die Afrikaanse gemeenskap kom (Gaum 2004:80).

Vyf jaar later het Geloftedag heeltemal van die voorblad van die Kerkbode verdwyn en verskyn daar 'n berig oor vigs in die uitgawe naaste aan Geloftedag/Versoeningsdag. Geloftedag kom in 'n enkele berig (op bl 7) ter sprake, maar die swaai weg van 'n tradisionele beskouing rakende Geloftedag is hiermee voltrek.

\section{Ds JC Symington (2004-2009)}

Ds Johann Symington neem in 2004 by dr Gaum oor as redakteur. In 'n hoofartikel op 23.11.2007 skryf die Kerkbode in die gees van die tyd: "Die roeping van die kerk is die deprogrammering en bevryding van die kultuurgekolonialiseerdes en die uitlei na die beloofde land." Pas voor 16 Desember verskyn die uitgawe van 7.12.2007 sonder 'n enkele verwysing na Geloftedag. 


\section{Ds AM Pienaar (2009-2010)}

In ds Anton Pienaar se kortstondige redakteurskap verskyn 'n artikel deur dr Johan van der Merwe wat Geloftedag weer op die agenda plaas. Hy vertel kortliks die geskiedenis van die gelofte en stel dit pertinent: "God het ingegryp en sy kinders gered!" (Van der Merwe 2009). Tog is dit nie 'n voortsetting van die ou teologie rondom Geloftedag nie. Hy meen die dag is "vrygemaak van sy eksklusiwiteit en politieke kleur en het 'n heel nuwe betekenis gekry ..." En dit is een van versoening. Die uitgawe van 3.12.2010, waar Pienaar vir oulaas as redakteur aangedui word, verwys egter glad nie na die gelofte nie.

\section{Gevolgtrekkings}

Drie benaderings tot die viering van die gelofte kom uit die analise na vore. Ten eerste is die tradisionele viering of nakoming van die gelofte vir meer as agt dekades sterk deur die Kerkbode aangemoedig. Daarna volg 'n meer ambivalente tyd van politieke magsverlies waar vrae gevra is oor die relevansie en betekenis van die viering, en uiteindelik verdwyn Geloftedag heeltemal van die Kerkbode se agenda. En tog is daar in 2009 weer 'n poging om sin daarvan te maak. Dus is hier dalk nie 'n finale afskeid van Geloftedag te bespeur nie, maar wel 'n herbesoek van die saak wat aansluit by Gaum se benadering.

Watter moontlike rol die Kerkbode gespeel het in die ontwikkeling van 'n Afrikanernasionalisme en gepaardgaande apartheidteologie wat gebou is rondom die Afrikaner se verstaan van die gelofte by Danskraal, word nou aan die hand van die vroeër genoemde teoretiese punte bespreek.

\section{Hoe het die Kerkbode sy lesers se agenda bepaal of medebepaal?}

Die media stel'n bepaalde agenda wat medebepaal waaroor mediagebruikers dink en of hulle dit belangrik ag al dan nie (De Beer \& Botha 2008:238240). Uit die voorafgaande is dit duidelik dat die Kerkbode die gelofte en die viering daarvan deur die jare taamlik konstant op die agenda gehou het. Daar was wel jare voor die nuwe politieke bedeling waarin geen verwysing na Dingaansdag/Geloftedag gevind is nie (bv 1910, 1940 en 1951). Redakteurs het ook nie met dieselfde entoesiasme oor die gelofte geskryf (of laat skryf) nie. Dr Andries Treurnicht het duidelik sterker oor 
die saak gevoel as byvoorbeeld dr M van der Westhuyzen. Die Kerkbode onder ds Tappies Möller het ruim aandag aan Geloftedag gegee sonder dat sy eie mening ooit opgeval het. Hoewel dit op die oog af lyk of ds PGJ Meiring en dr Willie Lubbe nie self veel oor die gelofte geskryf het nie, mag ander faktore (soos die Du Plessis-saak of Lubbe se kort termyn) 'n rol gespeel het.

By die latere redakteurs staan dr Frits Gaum se tyd in die teken van herbesinning in die lig van ingrypende politieke veranderinge. Hy het nie weggeskram van die teologiese uitdagings wat dit gestel het nie, en uiteindelik gekies téén die tradisionele opvattings. Meer nog was dit die geval met sy opvolger ds Johann Symington, maar onder ds Anton Pienaar is daar tog weer oor die saak besin - maar dan nie deur terug te gryp na die ou opvattings nie.

Saam met die ander media (alle nasionaalgesinde Afrikaanse koerante en die Afrikaanse diens van die SAUK) het die Kerkbode in die tydperk voor 1996 dus medebepaal dat Dingaansdag/Geloftedag belangrik was. As sodanig het die blad'n bepaalde invloed op sy lesers gehad. Maar daardeur is nog nie veel oor die standpunte as sodanig gesê nie.

\section{Hoe kon die Kerkbode standpunte oor Geloftedag versterk en/of verander?}

Die media "raam" gebeure op 'n bepaalde wyse en kan daardeur mediagebruikers se beskouing van gebeure of 'n situasie beïnvloed en kondisioneer ons om bepaalde betekenis aan gebeure, woorde en konsepte te heg. Die media kan dus ook bestaande standpunte versterk (Fourie 2007:321, 242). Die wyse waarop Dingaansdag/Geloftedag deur die Kerkbode geraam is (deurdat bepaalde woorde en beelde geselekteer is), is daarom belangrik. Dit word ook wyd aanvaar dat mediagebruikers se standpunte oor tyd heen verander indien hulle konsekwent via verskillende media aan 'n bepaalde alternatiewe standpunt blootgestel word (Fourie 2007:238, 239; DeFleur \& Dennis 1991:560-565).

Desondanks is media-effekte' $n$ besonder moeilike kwessie wat nie by nabaat met enige stelligheid wetenskaplik vasgestel kan word nie (vgl Severin \& Tankard 1988:265; DeFleur \& Dennis 1991:556). McQuail en andere, soos Fourie (2007:264-265), maan daarom teen simplistiese aannames oor die 
effek van die media. Daar moet byvoorbeeld onderskei word tussen die invloed op die direkte gebruiker en diegene wat indirek aan die inhoud blootgestel word.

Die stem van die Kerkbode, soos verwoord deur sy verskillende redakteurs en medewerkers, was boonop nie eenvormig nie. Waar die Afrikaner wel vir lank as volk beskou is wat 'n besondere band met God het (soos vergestalt in die gelofte), het hierdie siening later versag. Uiteindelik is vrae gevra en die herdenking selfs geïgnoreer. Indien die blad sy lesers vir lank beïnvloed en selfs gekondisioneer het om pro-Geloftedag te wees, moet ook erkenning gegee word aan die moontlikheid dat die verdwyning van Geloftedag van die Kerkbode se nuusagenda ook 'n bevestigende rol kon gespeel het by diegene wat buitendien (of mettertyd) nie erg gehad het aan die tradisionele viering van die dag nie.

Hier moet die groter konteks en tydsgees beklemtoon word waarbinne Kerkbode-lesers en lidmate in die algemeen die dominante ideologie nie meer klakkeloos aanvaar het nie, maar dit begin bevraagteken het en selfs toenemend geopponeer het (kyk Stuart Hall se argument oor preferred reading, soos verwys na deur Pitout, 2007:281-283). Die kern daarvan is dat ideologiese diskoerse nie geslote is nie en oop is vir verskillende interpretasies. Die meerderheid van die wit kieserskorps het inderdaad in die 1990's weggedraai van die ou apartheidsdenke nadat pres FW de Klerk die koersverandering op 2 Februarie 1990 aangekondig het. Terselfdertyd het die Kerkbode sy lesers geleidelik blootgestel aan 'n alternatiewe kyk op Geloftedag. Indien die Kerkbode vir lank 'n rol gehad het in die vestiging van Geloftedag op bepaalde teologiese en historiese aannames, kon die blad seker ook 'n rol gespeel het in die bevraagtekening en selfs verwerping van daardie aannames.

Die invloed van die Kerkbode as blad van die grootste en invloedrykste kerk onder Afrikaners (ten minste vir 'n groot deel van die twintigste eeu) was dus nie deurgaans eenvormig nie en is sekerlik nie deur alle lesers dieselfde geïnterpreteer nie. Tog meen ek dit is redelik om te aanvaar dat in die periode 1910 tot rondom 1990 die blad 'n grotendeels versterkende en selfs vormende rol gespeel het in die verstaan van Geloftedag. 


\section{Hoe kon die Kerkbode nie-lesers via predikante beïnvloed het?}

Die tweestapvloeimodel, wat later uitgebrei is tot die multistapvloeimodel, kan in kombinasie met agendastelling help verduidelik hoe die media 'n effek op mediagebruikers en selfs nie-gebruikers kan hê (vgl Zucker, aangehaal deur Severin \& Tankard 1988:277). Meer spesifiek kan ons sê: In terme van die multistapvloeimodel kan 'n medium (soos die Kerkbode) via 'n geloofwaardige persoon (soos 'n leraar) ander (soos sy gemeentelede) beïnvloed (Severin \& Tankard 1988:202,203; Littlejohn \& Foss 2008:321). Die argument is dus dat selfs lidmate wat nie die Kerkbode self gelees het nie tog daardeur beïnvloed kon word omdat hul leraars dit wel gelees en deurgegee het.

Om hierdie argument effe breër uit te pak, sou ons kon sê dat die preke (en ander artikels) in die Kerkbode deel was van die inhoud waaraan leraars blootgestel was en wat die konteks help vorm het waarbinne leraars oor Geloftedag gedink het en preke of toesprake moes voorberei. Daarna is hierdie preke of toesprake gelewer en is die bepaalde dominante denke oor die Gelofte, soos in die Kerkbode verwoord, ook aan lidmate oorgedra. In die tyd voor 1960 is hierdie aanname selfs meer toepaslik omdat daar in die eerste helfte van die twintigste eeu geen televisie, min radiostasies en beperkte leesstof beskikbaar was.

Hierdie aanname is direk gekoppel aan die kwessie van brongeloofwaardigheid: mense glo iemand wat geloofwaardig is (soos 'n dominee) eerder as iemand wat nie hulle vertroue geniet nie. Die voorbehoud is wel dat meningsvormers nie noodwendig oor alles as gesaghebbend beskou word nie (Littlejohn \& Foss 2008:321). Waar dit hier gaan oor die kwessie van Geloftedag kan aanvaar word dat in soverre leraars binne die dominante denke van hulle tye gebly het, die meerderheid lidmate dit nie sou bevraagteken het nie.

Die inhoud en rol van preke staan dus sentraal in hierdie argument. Belangrik is Cilliers (2003) se navorsing oor preke in die Kerkbode. Cilliers voer aan dat die prediking (in die tydperk 1960-80, wat deur hom ondersoek is, maar sekerlik ook vroeër - JDF)

... 'n Noemenswaardige invloed uitgeoefen het op die denkklimaat, nie alleen van die plaaslike gemeentes nie, maar ook van die breër bevolking onder wie die Nederduitse Gereformeerde Kerk werksaam 
was en is. Die rol van die prediking as meningsvormer moet nie oorskat, maar ook nie onderskat word nie, veral as dit handel oor die legitimering en bestendiging van bestaande godsdienstige en sosiale profiele ...

Die inhoud van Geloftedagpreke is nie die fokus van Cilliers se ondersoek nie, maar belangrik is sy bevinding dat die prediking nie (meer) as 'n vreemde, kritiese en daarom verlossende woord van God in die volk se situasie gefunksioneer het nie, "maar bloot as 'n sanksionerende en stabiliserende woord" (Cilliers 2003). Indien hierdie bevinding juis is en oor 'n breër front voorgekom het, het dit wesenlike implikasies vir preke op Geloftedag.

Hierby kan gevoeg word dat die media in byvoorbeeld die politiek belangrike 1980's gereeld die Kerkbode se standpunte aan 'n veel wyer gehoor oorgedra het (vgl Froneman 2000). Soos 'n oud-redakteur van die blad dit gestel het: die Kerkbode het 'n sirkulasie gehad wat deur die jare van 10000 tot 50000 gewissel het, maar sy invloed was soms "baie meer ... as wat sy verspreidingsyfer laat vermoed" (Gaum 2008:585). Later het hierdie potensiële invloed merkbaar afgeneem soos wat die kerk (en sy blad) se prominensie in die media getaan het.

\section{Slot}

Om die effek van mediakommunikasie op gebruikers met stelligheid by nabaat te bepaal, is uiters moeilik indien nie onmoontlik nie. Daarom was die fokus van hierdie artikel primêr die wyse waarop die Kerkbode aan Geloftedag aandag geskenk het. Dit is op sigself 'n insiggewende verhaal. Omdat die vraag na effek egter altyd opduik, is dit wel ook aan die orde gestel en aangetoon waarom daar tog met versigtigheid aangevoer kan word dat die Kerkbode waarskynlik direk en indirek 'n invloedryke rol in die vorming van Afrikanermenings oor Geloftedag gespeel het. Die basis van enige sodanige aannames sal steeds die artikels wees wat met soveel oortuiging geskryf is en oor soveel jare op die Kerkbode se bladsye voorgekom het. 


\section{Bibliografie}

Anon. 1945. Piekniekgees op Geloftedag. Die Kerkbode, 28.11.1945.

Arendt, WF 1970. Dingaansdag. Die Kerkbode, 16.12.1970.

Bailey, A 2002. Die gelofte van 16 Desember 1838: Die herdenking en betekenis daarvan, 1838-1910. Ongepubliseerde MA. Pretoria:

Universiteit van Pretoria.

Cilliers, JH 2003. 'n Eggo van Afrikaner-nasionalisme: 'n homiletiesanalitiese terugblik op Nederduitse Gereformeerde prediking uit die jare 1960 - 1980. Scriptura 84 (2003), 353-363.

De Beer, AS en N Botha 2008. News as representation. In: Fourie, PJ, red., Media Studies (Volume 2). Kaapstad: Juta. 227-42.

DeFleur, ML \& Dennis, EE 1991. Understanding mass communication. Boston: Houghton Mifflin.

De Gruchy, JW 1986. The church struggle in South Africa. Grand Rapids: Wm. B Eerdmans.

De Klerk, WA 1976. The Puritans in Africa. Manchester: Penguin Books.

De Klerk, WA 1979. Tyd van vernuwing. Kaapstad: Tafelberg.

De Swardt, AH 1930. 'n Dingaansfeesbelofte. De Kerkbode, 17.12.1930.

Diamond, GJ 1930. Dingaansdag. De Kerkbode, 17.12.1930.

Diederichs, P \& De Beer, AS 1998. The fourth estate: a cornerstone of democracy. In: De Beer, AS, ed., Mass media. Towards the millennium, Pretoria: Van Schaik. 85-118.

Fourie, PJ 2007. The effects of mass communication In: Fourie, PJ, red., Media Studies (Volume 1). Kaapstad: Juta. 228-68.

Froneman, JD 2000. Die media as medespeler in die kerklike waterskeidingjaar 1982. Studia Historiae Ecclesiasticae, XXVI:1.

Froneman, JD 2004. Dominante motiewe in die transformasie van Huisgenoot, 1916-2002. Ecquid Novi, 25(1). 
Froneman, JD 1995. Die kommunikasie van Afrikanernasionalisme deur Stellenbosse studente, 1902-1948. Ongepubliseerde PhD. Potchefstroom: PU vir CHO.

Froneman, JD 2012 Wolk oor SAUK van apartheidsjare. http://mediamense. co.za/index.php?frontend_action=display_compound_text_content\&item_id=3037

Froneman, JD 2013. Redakteurs nog altyd in spervuur. http://debat.maroelamedia.co.za/2013/03/15/redakteurs-nog-altyd-in-spervuur/

Gaum, F 2004. Op pad met God en mense. Kaapstad: Ex Animo.

Gaum, FM 2010. Kerkbode ná 160 jaar. http://reference.sabinet.co.za/webx/access/ electronic_journals/ngtt/ngtt_v51_supp1_a8.pdf

Gaum, F 2008. Kerkbode. In: Gaum, FM, Boesak, A en Botha, W, reds., Christelike Kernensiklopedie. Wellington: Lux Verbi. 585.

Gerdener, GBA 1914. Dingaansdag. De Kerkbode, 10.12.1914.

Gerdener, GBA 1968. God kies ons erfdeel. Die Kerkbode, 11.12.68.

Giliomee, H 2003. The Afrikaners. Kaapstad: Tafelberg.

Giliomee, H 2004. Die Afrikaners. Kaapstad: Tafelberg.

Giliomee, H 2012. Afrikanernasionalisme, 1875-1899. In: Pretorius, F, red., Geskiedenis van Suid-Afrika. Kaapstad: Tafelberg. 219-232.

Giliomee, H \& Mbenga, B 2007. Nuwe geskiedenis van Suid-Afrika. Kaapstad: Tafelberg.

Grobler, J 2007. Uitdaging en antwoord. Pretoria: Groerie.

Hofmeyr, JH 2002a. Een liggaam en een Gees. In: Hofmeyr, G, red., NG Kerk 350. Wellington: Lux Verbi BM. 198,199.

Hofmeyr, G (red). 2002b. NG Kerk 350. Wellington: Lux Verbi BM.

Kerkbode (De/Die). Hoofartikels, 16.12.1920, 14.12.55, 13.1.1961, 13.12.67, 16.12.1970, 8.12.1982, 20.12.1996, 23.11.2007.

Die Kerkbode 140, 1989.

Die Kerkbode, Feesuitgawe 150 jaar, 1999.

Kerkbode 155 jaar, 2004. 
Littlejohn, SW \& Foss, KA 2008. Theories of Human Communication. Boston: Wadsworth Cengage Learning.

McQuail, D 1987. Mass communication theory. London: Sage.

Meiring, AM 1945. Met die oog op Dingaansfees. Die Kerkbode, 12.12.1945.

Meiring, P s.a. Ds PGJ Meiring. Die lig op sy pad. Pretoria: PMP-uitgewers.

Muller, CFJ 1990. Sonop in die suide. Kaapstad: Nasionale Boekhandel.

Olivier, AR 1998. Bode op die spoor van die Woord. Kaapstad: Lux Verbi.

Oosthuysen, LF en Scholtz, JJJ 1992. In: Beukes, WD, red., Oor grense heen, Kaapstad: Nasionale Boekhandel. 210-219.

Pitout, M 2007. Media culture. In: Fourie, PJ, red., Media Studies (Volume 1). Kaapstad: Juta, pp. 281-283.

Rossouw, PL 1970. Brief. Die Kerkbode, 16.12.1970.

Scholtz, L 2011. 'n Gemaakte heiligheid. Beeld, 19.8.2011. http://www.beeld. com/Rubrieke/Gasrubriekskrywers/n-Gemaakte-heiligheid-20110819

Severin, WJ \& Tankard, JW 1988. Communication theories: origins, methods and uses in the mass media. New York: Longman.

Smit, AP 1938. Sarel Cilliers. Die Kerkbode, 14.12.1938.

Snijders, HJC 1971. Geloftedag: 'n Onontkombare verpligting. Die Kerkbode, 15.12.1971.

Steinberg, A 2007. An Introduction to Communication Studies. Kaapstad: Juta.

Steyn, GM 1983. Voorlaaierskote en Kersfeesklokke. Die Kerkbode, 2.12.1983.

Steyn, JC 2002. Penvegter. Piet Cillié van Die Burger. Kaapstad: Tafelberg.

Steyn, JC 1992. Die Volksblad. In: Beukes, WD, red., Oor grense heen, Kaapstad: Nasionale Boekhandel. 161-181.

Strydom, PCO 1952. Die Natalse kerk. In: Hanekom, TN, red., Ons NG Kerk, Kaapstad: NG Kerk-Uitgewers. 91-131. 
Swart, MJ 1961. President Steyn en Geloftedag. Die Kerkbode, 13.12.1961.

Thom, HB 1983. Prof. Thom se laaste Geloftedagrede. Die Kerkbode, 2.12.1983.

Van der Colf, AP 1971. Grootse Geloftefees te Bloedrivier. Die Kerkbode, 8.12.1971 bevestig

Van der Merwe, JM 2012. Die herdenking van die Gelofte van 16 Desember 1838 op Versoeningsdag: 'n nuwe uitdaging aan die kerk. http://repository. up.ac.za/bitstream/handle/2263/21371/VanDerMerwe_Herdenking\%282012\%29. pdf?sequence $=1$

Van der Merwe, J 2009. Geloftedag: Afrikaner is nie maar toevallig hier nie. Kerkbode, 4.12.2009.

Van der Merwe, JP 2011. Die Afrikaner se belewing van transformasie en nasiebou in 'n postapartheid Suid-Afrika. Tydskrif vir Geesteswetenskappe, 50(3): September 2010: 313-327.

Van Deventer, H 1998. Kroniek van 'n koerantman. Welgemoed: Tarlehoet.

Visagie, J 2002. 1838. Dingaansdag, Geloftedag, Versoeningsdag. In: Hofmeyr, red, NG Kerk 350, Wellington: Lux Verbi BM. 96,97.

Visagie, J 2012. Uittog en vestiging van Voortrekkers in die binneland. In: Pretorius, F, red., Geskiedenis van Suid-Afrika. Kaapstad: Tafelberg.142-150.

Vosloo, T 1982. Die redakteur - kaptein van die skip. In: De Beer, AS, red, Joernalistiek vandag, Kaapstad: Tafelberg. 12-24.

Willemse, GJ 1911. Overdenking op Dingaansdag. De Kerkbode, 7.12.1911.

Van Vuuren, JLJ 1983. Uiteenlopende gedagtes oor Geloftedag. Die Kerkbode, 2.12.1983. 